East European Politics

\title{
Patterns of competitive authoritarianism in the Western Balkans
}

\section{Florian Bieber}

To cite this article: Florian Bieber (2018) Patterns of competitive authoritarianism in the Western Balkans, East European Politics, 34:3, 337-354, DOI: 10.1080/21599165.2018.1490272

To link to this article: https://doi.org/10.1080/21599165.2018.1490272

(c) 2018 The Author(s). Published by Informa
UK Limited, trading as Taylor \& Francis
Group




\title{
Patterns of competitive authoritarianism in the Western Balkans
}

\author{
Florian Bieber \\ Centre for Southeast European Studies, University of Graz, Graz, Austria
}

\begin{abstract}
The countries of the Western Balkans during the 1990s were dominated by competitive authoritarian regimes that combined multi-party elections with nationalist rhetoric and the privatisation of the state to affiliated business interests. After a move towards democratisation in the early 2000s across the region, authoritarian practices began re-appearing in the late 2000 s and have now firmly taken root in many of these countries. This article will argue that the current competitive authoritarian systems (Levitsky, Steven, and Lucan A. Way. 2010. Competitive Authoritarianism. Hybrid Regimes after the Cold War. Cambridge: Cambridge University Press) are structurally different from those of the 1990s. These new regimes draw on the failure of reformist governments during the early 2000s to decisively break with authoritarian practices and establish independent and democratic institutions, thus facilitating the return of competitive authoritarian regimes. The current pattern in the Western Balkans is part of a global trend, but is also one embedded in the particularities of democratic transformation of the region. This article argues that the return of competitive authoritarianism is the result of weak democratic structures, facilitated by the weakening and insufficient transformative power of external actors, first and foremost the EU, in incentivizing continued democratisation.
\end{abstract}

\section{ARTICLE HISTORY}

Received 16 August 2017

Accepted 11 May 2018

\section{KEYWORDS}

Balkans; authoritarianism;

European Union;

democratisation

The countries of the Western Balkans were dominated during the 1990s by competitive authoritarian regimes that combined multi-party elections with nationalist rhetoric and the privatisation of the state to affiliated business interests. After a move towards democratisation in the early 2000 s across the region, authoritarian practices began re-appearing in the late 2000s and have now firmly taken root in many of these countries. This article will argue that the current competitive authoritarian systems (Levitsky and Way 2010) are structurally different from those of the 1990s. These new regimes draw on the failure of reformist governments during the early 2000s to decisively break with authoritarian practices and establish independent and democratic institutions, thus facilitating the return of competitive authoritarian regimes. The current pattern in the Western Balkans is part of a global trend, but is also one embedded in the particularities of democratic transformation 
of the region. This article argues that the return of competitive authoritarianism is the result of weak democratic structures, facilitated by the weakening and insufficient transformative power of external actors, first and foremost the European Union (EU), in incentivising continued democratisation.

The focus on the Western Balkans derives from its position outside the EU. Similar patterns of rising authoritarianism can be identified inside the EU, such as in Hungary and Poland, while other EU members display comparable patterns of weak institutions, corruption and limited media freedom, such as Romania and Bulgaria. Furthermore, countries more distant from the EU, geographically and in terms of membership such as Turkey, also display strong authoritarian traits. The focus on the Western Balkans thus does not suggest a regional specificity, but instead argues that with close EU engagement in the region and pre-accession conditionality, governments in the Western Balkans are more likely to have strong incentives to foster democratic rule than those either inside or more distant from the EU.

Since the introduction of multi-party democracy in the early 1990 s, most of the Western Balkans ${ }^{1}$ have experienced a variety of hybrid regimes that fall in the spectrum between consolidated democracies and autocracies (Bogaards 2009). The wars in Croatia, BosniaHerzegovina, and Kosovo and competitive authoritarian regimes characterised the 1990s. The first decade of the 2000s began with a gradual democratisation that saw a regular alternation of power, ruling parties that endorsed political and economic reform, as well as EU integration. By the late 2000s, competitive authoritarian patterns reemerged including a decline in press freedom, erosion of independent institutions, and strong reliance on informal control over the state administration by the ruling party (Kmezić and Bieber 2015). This downward trend or in some countries merely stagnation is reflected in all key indices of democracy. ${ }^{2}$

As this article will argue, the competitive authoritarian regimes that have emerged are best understood as being defined by the combination of two features: (1) institutional weakness that provides insufficient democratic safeguards, and (2) authoritarian political actors who utilise these weaknesses to attain and retain power. The weakness of democratic institutions also characterised the 2000s throughout the Western Balkans, but what has changed in the last decade in some of the countries is the use of these weaknesses of elected governments and presidents to consolidate power. Modest advances in creating independent institutions and checks and balances have been reversed in a number of cases. The main variation across the region is found less among weak institutions, and more among authoritarian parties and leaders taking advantage of them.

A second aspect of competitive authoritarian regimes often neglected and essential in understanding the Western Balkans is the role of outside actors. Much of the support, both financial and normative, as well in terms of pressure and incentives for democratisation came from the larger process of integration into European institutions, from the Council of Europe (especially in the early years) to the North Atlantic Treaty Organisation (NATO) and the EU. A lack of strong support for democratic rule by the EU and several of its member states has facilitated the emergence of regimes that base their external legitimacy on providing stability, rather than democracy. The nexus between competitive authoritarian regime and strategic external support and the legitimacy this generates has been termed "stabilitocracy" (Primatarova and Deimel 2012; Pavlović 2016b; Beha 2017; BiEPAG 2017; Bieber 2018). The central role of external support for competitive 
authoritarian regimes in the Western Balkans will be a central theme in the article, as this constitutes their defining feature and a neglected aspect in the study of competitive authoritarian regimes. ${ }^{3}$ In conclusion, this article will identify both lessons for the engagement of external actors in the Western Balkans, as well as future paths for research on competitive authoritarian regimes.

\section{Competitive authoritarianism in the Western Balkans}

After the initial post-1989 euphoria over the supposed victory of liberal democracy, a more nuanced understanding of democratisation emerged from the late 1990s that acknowledges the many nuances between a fully consolidated liberal democracy and an outright authoritarian regime. These "in-between" regimes have been given a variety of names from semi-authoritarianism (Ottaway 2003) to hybrid regimes (Diamond 2002) and defective democracies (Merkel 2004). As Bogaards convincingly argues, and as major indices show, the best way to conceptualise these types is as lying in a continuum between an ideal type of democracy and authoritarianism and to position regimes accordingly (2009). For the purposes of this article, I will use the term of competitive authoritarian systems, as defined by Levitsky and Way $(2010,5)$, meaning

\footnotetext{
"civilian regimes in which formal democratic institutions exist and are widely viewed as the primary means of gaining power, but in which incumbents' abuse of the state places them at a significant advantage vis-à-vis their opponents. Such regimes are competitive in that opposition parties use democratic institutions to contest seriously for power, but they are not democratic because the playing field is heavily skewed in favor of incumbents."
}

In addition the emergence of a more nuanced understanding of the gradations of regime types between ideal type democracy and authoritarianism, there has also been an observable global decline of democracy in recent years (Diamond and Plattner 2015; Bermeo 2016), although some authors have been sceptical about the extent to which democracy has declined (Levitz and Pop-Eleches 2010; Levitsky and Way 2015). This decline is distinct from, yet closely linked to the rise of nativist and populist politicians and parties which challenge liberal democratic regimes (Krastev 2007, 2011; Mudde and Kaltwasser 2016), as it is often populist and nativist parties in power that can become responsible for the democratic decline. Importantly, the rise of illiberal politics has occurred in both consolidated democracies such the United States and Hungary, as well as democracies with weak institutions like Macedonia, the Philippines or Turkey.

This twin global challenge of competitive authoritarian regimes and illiberal politics in consolidated democracies highlight that the Western Balkans are not experiencing an isolated decline of democracy, but part of a larger pattern. The countries of the Western Balkans belong to the large group that has not achieved the status of consolidated democracy (Bieber and Ristić 2012, 529-549; Džihić and Segert 2012).

Over the past two decades, considerable scholarly attention was given to nationalism and competitive authoritarian regimes in the post-Yugoslav space during the 1990s (Gordy 1999; Gagnon 2004; Boduszyński 2010; Dolenec 2013). Yet studies embedding the Western Balkans in the larger debates of democratisation have been fewer (Fisher 2006), and research on post-Communist democratisation has often left out the post-Yugoslav space (Bieber 2014; Vladisavljević 2014). ${ }^{4}$ 
Scholarship on the Western Balkans after 2000 often rested on the assumption that the region was merely experiencing a delayed process that would emulate the larger postCommunist pattern of democratisation, namely the transformation of authoritarian to democratic regimes (Cohen and Lampe 2011). More critical and nuanced assessments of the difficulties of democratic consolidation in the Western Balkans, both comparing beyond the region and/or reflecting on the marginal position of the region in the democratisation literature, have emerged only recently (Džihić and Segert 2012; Dawson 2014; Günay and Džihić 2016; Mujanović 2018). The focus on the Western Balkans in this article is thus not an argument for the region's exceptionalism, but rather to understand new competitive authoritarianism in the context of a region that has high levels of Western linkages and where EU leverage is particularly large.

Thus, the core argument of the article is that the competitive authoritarian regimes that have emerged in the Western Balkans have adapted to the challenge of maintaining external support by largely Western actors, the EU, its member states and the United States, while ensuring authoritarian control domestically. Anti-Western policies and exclusionary nationalism are only used when the combination of competitive authoritarian practices and a formal reformist agenda fail. Second, these regimes exercise control informally rather than through constitutional and legal change, taking control of the media and the state institutions (Bieber and Kmezić 2015). Third, the competitive authoritarian regimes of the Western Balkans rely strongly on external legitimacy as "reformers", at least initially, yet govern through the creation and management of crises.

In the Western Balkans, I consider three examples of clear competitive authoritarian regimes: Serbia since 2012, Montenegro, and Macedonia between 2006/8 and 2017. The remaining countries, Albania, Kosovo and Bosnia-Herzegovina, are partially competitive authoritarian regimes. In Bosnia-Herzegovina, the regime in one entity, the Republika Srpska since 2006 fits, whereas in the other entity, the Federation, there has been more regular alternation of power and a lower level of distortion of electoral competition. However, some features of competitive authoritarianism are to be found in the Federation, and also in Kosovo and Albania (both of which have seen more frequent alternations of power), such as weak institutions, use of state resources and institutions by ruling parties. Finally, Croatia could be included, as it was included in the "Western Balkan" region prior to EU accession. While it joined in 2013, it displays features similar to the other countries. Here, the hegemonic conservative Croatian Democratic Community (Hrvatska demokratska zajednica, HDZ) ruled for 20 of the 28 years since the introduction of multiparty system. Yet, since returning to power in 2016 it has not displayed the ability to establish the kind of dominant position to transform the country into a competitive authoritarian system.

The regional variation is also reflected in various democracy indices that provide a somewhat misleading picture at the comparative level (Bertelsmann Transformation Index 2016; Economist Intelligence Unit 2016; Freedom House 2016). All three list Serbia and Montenegro as regional leaders, with Kosovo and Bosnia-Herzegovina being the laggards. However, the contested nature of both states impacts on the measure of democracy, as does blocked decision-making and external intervention. The fact that much of the competitive authoritarian rule takes place informally, not through laws and formal decisions, means that the comparative rankings are misleading. There are thus two features to consider, as noted earlier: (1) the structural weakness of democratic institutions, 
which are shared across the region and which make institutions less resilient; and (2) the ability and willingness of ruling parties and individuals to use these weaknesses to their advantage.

The article will identify five central features of competitive authoritarian systems in the Western Balkans: ideology, external legitimacy, crises, control of media, and state capture. In conclusion, the article will highlight how the new competitive authoritarian regimes have incorporated demands for reforms and external legitimacy into classic mechanisms of control, using informality and reform discourse.

\section{Patterns of competitive authoritarianism}

By the late 1990s, the competitive authoritarian regimes of the Western Balkans lost power through breakthrough elections (Albania, Croatia and Serbia) or transformed themselves (partially Montenegro and Macedonia). ${ }^{5}$

The emergence of new competitive authoritarian regimes occurred during the 2000s, with Montenegro merely transforming the more repressive competitive authoritarianism of the 1990s into one that was pro-Western, rhetorically reformist and tolerated greater opposition (Vuković 2015).

In Croatia and Serbia the early 2000s marked the highpoint of the democratic transformation, complicated by the return of the HDZ in Croatia and the unstable and more conservative governments in Serbia after Đinđić's assassination in 2003. Initially, both continued to establish independent institutions and move gradually towards the consolidation of democracy. In Croatia, the HDZ under Prime Minister Ivo Sanader and his successor Jadranka Kosor continued to pursue EU integration and institutional reforms, whereas in Serbia the consolidation was complicated by the strength of the anti-reformist Serb Radical Party (Srpska radikalna stranka, SRS) until 2008. Only then did the SRS split with a moderate wing led by Tomislav Nikolić and Aleksandar Vučić forming an ostensibly pro-reformist and EU-friendly Serb Progressive Party (Srpska napredna stranka, SNS) (Konitzer 2011). In Serbia, reformists were also only reluctant institution-builders. Thus, rather than decisively breaking with undemocratic practices, they continued to rely on them and were often unwilling to strengthen independent institutions and constitutions (Orlović 2008). An example is the strong control of the executive under the second term of president Boris Tadić (2008-2012), when he controlled the government, led by his party DS, and the prime minister, Mirko Cvetković, was a lacklustre candidate, with no independent power base. In 2012 the SNS won presidential and parliamentary elections and in subsequent years, the party and its leader Aleksandar Vučić gradually consolidated power, winning presidential elections in the first round in 2017.

In Macedonia the Internal Macedonian Revolutionary Organization - Democratic Party for Macedonian National Unity (Vnatrešena Makedonska revolucionerna organizacijaDemokratska partija za Makedonsko nacionalno edinstvo, VMRO-DPMNE) came to power in 2006 on a reformist moderate agenda. It held power between 1998 and 2002 and took a nationalist, but not an authoritarian line. It initially focused on economic reforms, while also excluding the larger Albanian party, the Democratic Union for Integration (Bashkimi Demokratik për Integrim, BDI), established from the rebel movement in 2001, from power. After the rejection of NATO membership over Greek objections over the name, the party shifted towards more nationalist and authoritarian rule in 2008, even if the 
lavish reconstruction plan "Skopje 2014" that introduced nationalist monuments, museums and other markers was planned before 2008. Prime Minister Nikola Gruevski increasingly undermined democratic rule, including manipulation of elections, closure of critical media and pressure on journalists and independent institutions revealed after wiretaps of some 20,000 citizens were partially published by the opposition in 2015 . The turn towards competitive authoritarian politics was accompanied by the lavish reconstruction of the centre of Skopje in a panache of architectural styles and nationalist symbols that cost more than half a billion Euros (Jordanovska 2015). In Bosnia-Herzegovina, similarly, Milorad Dodik became prime minister of Republika Srpska in 2006 on a reformist moderate agenda, winning elections later that year launching a nationalist platform of promising a referendum on independence. He moved to the presidency of Republika Srpska in 2010. His use of a nationalist position was both the result of foreign campaign advice, the nationalist electoral base, and enhanced by the contentious, ethnically segregated political system that encourages nationalist polarisation.

All competitive authoritarian regimes were elected as pragmatic reformers, from Milo Đukanović (Montenegro) in the late 1990s and later to Gruevski (Macedonia) and Dodik (Republika Srpska) in 2006 and Vučić (Serbia) in 2012. They enjoyed both domestic and external, Western support for their pragmatism. Shifts towards nationalism in Republika Srpska and Macedonia initially hinged largely on pragmatic considerations.

One key distinction of these new competitive authoritarian regimes from their predecessors is that they rely heavily external legitimacy, which restricts their ability to use violence or promote nationalism as they did during the 1990s (Gagnon 2004). In addition, they did not inherit an essentially authoritarian state, but founded their rule on flawed, yet democratic institutions. Following privatisations, the reduction of the public sector, and other aspects of transformation during the 1990s and early 2000s, the governments taking office in the late 2000s lacked the same arsenals and resources for clientelism that governments had during the 1990s (Fisher 2006, 83-100).

This means that they could not draw on the same continuity of direct control and instead had to rely on more subtle mechanisms of control. Thus, the institutions and practices of the democratic interlude matter. During the 2000s, the beginning of EU accession processes generated the expectation of and demand for political and economic reforms. In some cases, as in Montenegro, the transition from the more heavy-handed authoritarianism of the 1990s to the "EU-compatible" competitive authoritarian regimes of today was seamless, whereas in others, such as Serbia, a decade stood in between. In the case of Macedonia, the period prior to 2006 was characterised by undemocratic practices, but overall the regime did not really display competitive authoritarian features until 2008.

In discussing the competitive authoritarian regimes of today, we focus on five key traits: (1) strategic use of ideology; (2) the significance of external legitimacy; (3) crisis "management"; (4) control of the media; and (5) the dynamics of state capture. ${ }^{6}$ All features are based on negotiating external legitimacy as reformists (at least initially) and domestic control.

\subsection{Strategic use of ideology}

While the competitive authoritarian regimes of the 1990s were firmly rooted in nationalism, this ideological choice is less pertinent today. The ruling parties in Croatia and Serbia, 
as well as in Montenegro (until 1997) and Bosnia-Herzegovina were based on the use of nationalism, even if formally they identified themselves respectively as Christian democrats and socialists. Today, nationalism is less central to the regimes' ideological foundation, even if we find no single patterns, but rather two types of development. One, exemplified by Macedonia under VMRO-DPMNE, where nationalism became increasingly central to the government policy, and the other, exemplified by Montenegro under Democratic Party of Socialists (Demokratska partija socijalista, DPS) rule, where exclusionary nationalism has been marginal.

The decade of VMRO-DPMNE rule in Macedonia is characterised by conservative and nationalist policies. The use of nationalism became particularly pronounced following Macedonia's failure to join NATO in 2008 when the government began embarking on the megalomaniac-building project Skopje 2014 (Vangeli 2011). Serbia and Montenegro are, on the other hand, examples of non-ideological competitive authoritarian regimes. This does not mean that the governments of the two countries do not draw on nationalism, but that this is merely one part of their repertoires.

In Montenegro, the DPS regime adopted a catch-all platform of such broad scope that it is nearly impossible to pin down ideologically (Džankić and Keil 2017). The ruling party promoted Montenegrin state-building and a Montenegrin national identity that is distinct from Serb identity. However, as the party has relied on minority support among its electorate and from minority parties, this nationalism has not been exclusive and focused more on strengthening the state and underlining the separateness from the Serb nation, including through the introduction of the Montenegrin language with its own letters (Džankić 2013). Similarly in Serbia, despite having its roots in the extreme nationalist SRS, the ruling SNS has downplayed this legacy. Instead, it emphasises its rhetorical commitment to EU integration and to (ill-defined) economic and political reform (Stanković, Ćuković, and Vuksanović 2016).

With the SNS positioning itself as a centre-right party and the DPS as a centre-left party, their programmes and policies provide little insight into their position. Those two cases could be thus described as non-ideological autocrats, who do not openly espouse an illiberal state, but have rather achieved party control over the state in parallel to their formal commitment to EU integration.

VMRO-DPNME in Macedonia positioned itself as a pro-European and centre-right party. ${ }^{7}$ However, over time as a consequence of external blockages to progress towards EU accession, it has moved away from mainstream positions to endorse ideologies and policies on the far right (Petkovski 2015). However all parties aspired to membership in European party families, including VMRO-DPMNE and SNS as associate members of the European Peoples Party (EPP) and DPS as an associate member of the Party of European Socialists (PES). Only the Alliance of Independent Social Democrats (Savez nezavisnih socijaldemokrata, SNSD) of Milorad Dodik was expelled from the Socialist International in 2012 for its nationalist policies.

\subsection{External legitimacy}

A key feature of competitive authoritarian regimes during the 1990s was their limited international legitimacy. The government of Serbia (and Montenegro) was under UN sanctions between 1992 and 1995 and remained subject to an outer wall of sanctions 
afterwards, strengthened in the context of Kosovo war 1998-1999. Croatia and Bosnia-Herzegovina were not subject to sanctions, except the Yugoslav-wide weapons embargo of 1991-5. Croatia was able to build ties with EU members and the Tudjman government was able to make a more credible case for integration to international organisations than Serbia or the Federal Republic of Yugoslavia.

However, EU accession was not an option for Croatia, even after the end of the wars in 1995 and the peaceful reintegration of Eastern Slavonia in 1997. In Serbia (and Montenegro), the prospect of European integration was even more remote. Briefly, Milošević came to be accepted as a "peacemaker" in the Bosnian peace talks, given preference over the more radical Bosnian Serb leaders. Yet, that acceptance was always tentative and he was seen purely as a provider of stability, but not as a partner in Euro-Atlantic integration. With the indictment of Milošević by the ICTY during the Kosovo war in 1999, Milošević became internationally shunned and isolated. Thus during the 1990s the regimes of the Western Balkans could at best hope for strategic support as promoting stability, but full integration into Euro-Atlantic structure was neither on offer, nor actively sought by most governments. After 2000, nationalist and autocratic parties were excluded from power and could only return if they reformed or the country risked its integration in Euro-Atlantic institutions.

Montenegro best exemplifies the role of external legitimacy in shoring up competitive authoritarianism. Unlike in Croatia and Serbia, where there was a rupture in the rule of the dominant party of the 1990s, the DPS could transition from full autocratic rule in the 1990s to pro-Western competitive authoritarian rule. Through the government's support for Western policies, from toppling Milošević and Kosovo independence to NATO membership, and a clear commitment to EU membership, it gained important external support over the years. First, it was direct financial assistance and also recognition as a partner, and later the leadership position in the EU accession process. After Croatian EU accession in 2013, Montenegro was the only country with which the EU was in accession talks. Thus, the country became important in keeping the accession process alive so shortcomings were easily overlooked for the sake of expediency (Džankić 2014).

Above all, external legitimacy has been expressed in terms of formal advancement in the EU accession process. The technical steps along the way - candidate status, the opening of negotiations, the opening and closing of chapters - bestows legitimacy on governments, as they (appear) to confirm EU-approval. Besides the EU, NATO is the most important international organisation serving this purpose.

Bilateral ties, represented by state visits highlight external legitimacy and are important features in election campaigns. For example, Aleksandar Vučić visited German Chancellor Angela Merkel shortly prior to the election in April 2017 (Ernst 2017). The visit was given considerable attention in Serbian media and after his first round victory, he publicly thanked Merkel for meeting him so close to the elections ("Vučić" 2017).

Similarly, the electoral support of Austrian foreign minister Sebastian Kurz for the VMRO-DPMNE in the days before the December 2016 elections was an important boost (Marusic 2016). The daily Vest, supporting the ruling party, came out with the headline "Leader of the largest European political party gives strong support for VMRO-DPMNE" ("Liderot" 2016).

Importantly, all parties and their leaders began their rise to power as self-proclaimed "reformers," a position widely accepted and supported externally. From Nikola Gruevski 
to Milo Đukanović, and from Aleksandar Vučić to Milorad Dodik, all presented themselves as pragmatic politicians who offered a break with the past. They thus attained power not as radical candidates from the political margins, but with mainstream parties, connected to European party families. All could thus rely on external support, at least initially, which in turn reaffirmed their domestic position as reformers.

External legitimacy does not only serve to confirm popular support for EU integration and ties to EU member states. It also enables the competitive authoritarian regimes to undermine the opposition. If the government has received formal or de-facto recognition from the EU or its member governments, this relativises criticism of autocratic rule. The external legitimacy thus accorded to competitive authoritarian regimes can be termed "stabilitocracy" (Bieber 2018). Of course, this dynamic is by no means specific to the Western Balkans. Unlike elsewhere, however, the prospect for the countries of the Western Balkans to be incorporated into the EU presupposed a normative transformation, not relations based on stability at the price of democracy (Vachudova 2014).

\section{3. "Crisis management"}

An important pillar of competitive authoritarian regimes today is the management of crisis. What is meant by "crisis management" is not so much the conventional understanding of resolving or mitigating crises, as their creation and subsequent resolution. A number of authors have noted the broader use of security crises by authoritarian regimes, including competitive authoritarian ones (Snyder 2017; Levitsky and Ziblatt 2018, 191-192), from the Russian apartment bombings in 1999 facilitating Putin's rise to power (Treisman 2011) to the failed coup attempt in Turkey in 2016 that shifted Erdoğan's rule to a competitive authoritarian regime (Öktem and Akkoyunlu 2017). However, the Western Balkan cases of such security crises are less intense than the 2016 coup attempt and the subsequent crackdown and serve the more subtle function of highlighting (to Western actors) the importance of governments to ensuring stability and extending prolonged uncertainty among citizens.

Today, in the Western Balkans wars are no longer a resource easily available to autocrats. As Gagnon (2004) and Gordy (1999) have convincingly argued, the regimes in Croatia and Serbia used violence during the 1990 s as a strategy to both legitimise themselves, and to delegitimise and demobilise the opposition. Such a strategic use of mass violence was no longer as easily possible in the 2000s. First, the experience of the $1990 \mathrm{~s}$ is still very fresh and has acted as an important break on support for violence. Second, the use of violence would foreclose options and cost both external legitimacy and domestic support. Third, unlike in the 1990s when the arsenals of the Yugoslav army provided the resources to fight multiple wars, today, armies in the region are small in size, partially integrated into NATO, and large stockpiles of weapons have been destroyed in the past two decades.

Instead of instigating large-scale violence, we can instead observe the production of crisis. These crises come in three types. One is a crisis that includes a threat against the government and thus constitutes an opportunity to describe the opposition as traitors and/or identify foreign enemies. The second is focused on interethnic relations and the risk of renewed violence. The third is a crisis over bilateral relations with a neighbour and the creation of tensions. 
There are plenty of examples for these three types. The first type of crisis includes the supposed coups in Serbia in November 2015 (Radovanović 2015) and (a more real yet largely unclear) coup attempt in Montenegro in October 2016 (Hopkins 2017; Bechev 2018). Type two includes the shoot-out in Kumanovo (Macedonia) in May 2015 during the first wave of anti-government protests. The third type of crisis includes the "train incident" when Serbia sent a train with highly provocative markings ("Kosovo is Serbia" in multiple languages) to Mitrovica in January 2017 or the escalation between Serbia and Croatia during the peak of the refugee flow in September 2015.

All these incidents involve multiple and complex layers of event with different actors opting for escalation. It is often impossible to determine to what degree these incidents are fabricated or merely opportunistically used. They take place amidst a media environment that regularly accuses foreign powers, minorities and opposition parties of seeking the violent overthrow of the status quo, and many media loyal to governments talk of war on a daily basis.

"Crisis management" - both allowing (or causing) these crises and their subsequent deescalation to occur - serves the function of supporting regimes' legitimacy domestically and internationally. Domestically, they underline the danger of international and external threats and provide "extraordinary" circumstances that overshadow more mundane problems. They also serve the classic nationalist purposes of maintaining the threat of the other, be it from foreign powers (state, or other actor) or a minority or opposition party within. Second, they serve an important role externally as they highlight the external threat to a government and thus can shore up support. The alleged coup in Montenegro certainly helped to propel the ratification of the NATO accession as Western media could present the government and country as an important bulwark against Russian intervention in the Balkans. In addition, conflict resolution can serve to show state and government capacity for resolving conflicts.

Crisis management thus fulfils an important function in the nature of competitive authoritarian regimes. Their shadowy circumstances make a clear understanding of what happened in each of these incidents difficult, but one can clearly observe the strategic use of crises by governments. The use of emergencies by governments is not limited to non-democratic governments, but part of a larger pattern of "emergency politics" (White 2015).

\subsection{Re-establishing a loyal media}

One of the main pillars of democracy that emerged and thrived after 2000 was the independent media. Private media, sometimes with foreign ownership, as well as efforts to transform government-controlled media into public broadcasters, created fairly vibrant media scenes in the region (Irion and Jušić 2014). Independent media such as Radio $B 92$ in Serbia or the weekly Feral Tribune in Croatia, had already emerged in the region during 1990s, often with external support and under pressure from the government.

This level of independence has considerably decreased over the past decade (Kmezić and Bieber 2015; Vračić and Bino 2017). The transformation of government media into independent public broadcasters became stalled across the region, as most state media continue to favour the governments (Marko 2016). Among private media, lack of 
independence has been reflected in both the ownership structure, as well as the reporting. Critical and independent media during the 1990s either folded, as Feral Tribune in Croatia, or became largely uncritical through weak sales and the loss of their initial economic independence (usually precarious and donor-supported), as the case in the Serbian media group B92. Foreign media engagement in the region was strong in the 2000 s, but following the economic crisis and the general decline of print media, most have left the region including, notably, the German WAZ group which was once strong in Serbia and Macedonia. The more reputable external investors have been replaced with opaque ownership structures.

Furthermore, the economic crisis resulted in a reduction in advertising revenues, after which space was often filled by state advertising or advertising by companies under the direct influence or pressure of the state, such as energy and telecom providers. In Macedonia three of the largest newspapers Utrinski vesnik, Dnevnik, and Vest were owned by a company closely connected to the inner circle of former Prime Minister Gruevski (Cvetkovska, Jordanovska, and Apostolov 2014). These papers have been supportive of the VMRO-DPMNE government and hostile to the opposition.

Governments benefit from being overrepresented in loyal media, both in terms of coverage and content. Research during the Serbian presidential elections in March 2017 found that Aleksandar Vučić received more attention than all other candidates combined in all main TV stations. In the popular private TV Pink Vučić received more than $88 \%$ of the coverage for candidates, most of it overwhelmingly positive ("BIRODI" 2017).

Tabloid media close to the regimes also serve to attack the opposition, NGOs and other media. The most prominent example is the Serbian tabloid Informer, which has regularly engaged in hate speech at a level not seen in the region since the 1990s. It regularly attacks other nations, uses ethnically denigrating terminology regularly (e.g. Balija for Bosniaks, Šiptari for Albanians), and accuses the opposition of attacking and undermining the government. The paper regularly warns of imminent war or a coup.

In the 1990s influential media were still under state control and-or ownership, so the channel of governmental influence was more direct than today. Today, we can note that competitive authoritarian regimes rely on a combination of loyal media owned by businesses with murky and convoluted ownership structures, economic pressure on independent media and threats and censorship of journalists and media. ${ }^{8}$ Thus, control of the media constitutes a central element of the competitive authoritarian regimes, albeit less heavy handed than during the 1990s, with critical reporting in many cases available only through online platforms.

\subsection{State capture}

In its annual report on Macedonia in 2016, the European Commission for the first time used the term "state capture" to describe the institutions in an accession country "affecting the functioning of democratic institutions and key areas of society" (EC 2016). In early 2018, the European Commission extended the concept's reach to all countries of the Western Balkans in its new regional strategies to note that "the countries show clear elements of state capture, including links with organised crime and corruption at all levels of government and administration" (EC 2018, 3). This concept describes the control of state resources for illicit purposes by a small elite in control of the state 
(Fazekas and Tóth 2016). The small elite is, in the case of the countries under discussion, the leadership of the ruling parties.

This re-assertion of party control is articulated through the erosion of independent institutions, the penetration of state administration by party members and the use of informal mechanisms to secure control. The establishment during the early 2000s of independent institutions to comply with EU and Council of Europe requirements was a significant advance. These included ombudspersons and other regulatory and consultative bodies created with external support. In addition, considerable resources were invested in the reform of the judiciary and strengthening parliaments to ensure a separation of powers so these institutions could effectively oversee the work of governments. In comparison to the 1990s this was a significant change. During the 1990s the judiciary remained subordinated to governments and parliaments were underfunded, serving mostly to rubber stamp executive decisions or to make a mockery of democracy through polarising debates without any discernible substance usually broadcast live on TV. While these institutions have survived, they have been beset by institutional uncertainty and usually deprived of their independence.

The use of informality is often reflected in the exercise of power bypassing formal, legal mechanisms (Pavlović 2016a). Thus, unlike more ideologically based competitive authoritarian regimes in Hungary or Turkey, the governments of the Western Balkans have not promoted constitutional change to institutionalise the new power relations. With EU accession an important legitimising criteria, the weakness of ideology and an ability to bypass formal decision-making structures, informal power trumps constitutional changes (Djolai and Stratulat 2017). Informality also serves to subvert democratic processes. Elections in the region are tainted by a variety of schemes to influence the outcome through vote buying and pressure on vulnerable voters, especially those employed by the state or receiving state benefits, such as pensioners (Marović and Cvijić 2017). These dynamics came to light through the wire-tapping scandal in Macedonia, which revealed not only direct pressure on the media, but the manipulation of election results and the hiring of party members. Similar dynamics have been documented across the Western Balkans (Cvejić 2016).

The main challenge is to determine the dividing line between clientelism and largescale corruption that is a feature of many societies and state capture which fundamentally distorts the democratic process. The illicit nature of such practices makes such an assessment difficult, except in cases where their scale emerges through investigations, court cases and public disclosure. In regard to state capture, the mechanisms of rule are similar to the 1990s. The main difference has been the active rollback in recent years from (modest) advances towards rule of law made in the early 2000s. Thus, unlike before, the countries continue having independent institutions, but their ability to act as checks and balances are severely curtailed.

\section{Conclusions}

Competitive authoritarian regimes in the Western Balkans today and over the past decade distinguish themselves from their precursors of the 1990s in terms of their strategic use of ideology and legitimising strategies. Their governments are self-proclaimed centrists and have sought inclusion in international party families, as well as Euro-Atlantic integration. 
The main protagonists took office as reformers, often with considerable Western political and financial support. Over the duration of their rule, some, like Nikola Gruevski in Macedonia and Milorad Dodik in Republika Srpska have taken a strong nationalist position and increasingly distanced themselves from Euro-Atlantic integration. Others, like Milo Đukanović or Aleksandar Vučić have not.

The mechanisms of rule have also become subtler than during the 1990s. Media control is exercised indirectly through favouring media that support the governments and often act as their attack dogs. These private yet loyal media are often more effective and less restrained than the still loyal public media. The use of crisis rather than war to build legitimacy at home and to play the role of crisis manager internationally also reflects the constraints regimes encounter in comparison to the 1990s.

A crucial distinction arising from these differences is the importance of external legitimacy for the regimes. Such external recognition is a consequence of broad voter support for EU integration and other forms of cooperation with the EU, EU members and the United States. This leverage continues to act as a considerable (Vachudova 2014), yet diminishing, restraint on governments. It acts as a source of both voter demand and external pressure. Yet, the very rise of competitive authoritarian regimes highlights the weakness or limitations of this mechanism of restraint. As rulers seek and get external recognition, in terms of formal advancement towards the EU, there is little restraint.

It is no surprise that the regime that has responded least to the external legitimacy dynamic is Macedonia, which has been confronted with greater obstacles towards EU accession than Serbia or Montenegro due to the Greek veto over the name issue.

An important feature linking competitive authoritarian experiences in the 1990s and in more recent years is the democratisation efforts of the 2000s. While none of the countries discussed here, except Croatia, could be considered a consolidated or liberal democracy during the 2000s, it is tempting to downplay variation over time and just consider the competitive authoritarian regimes of today an extension of the 1990s. However, the 2000s represented too strong a rupture to authoritarian rule in the Western Balkans to be ignored.

This article has identified patterns of competitive authoritarian regimes in the last decade, highlighting continuity and adaptation to the 1990s. Thus, the current regimes are not the direct successors to earlier competitive authoritarian regimes, even if some of the clientelistic networks in power today originate in the 1990s. Instead, they draw on the interim democratic reforms of the early 2000s and respond to the demand of their citizens for EU accession and the importance of securing external legitimacy.

The declining engagement of the EU in the Western Balkans and the crisis of EU accession have reduced the restraining and transformative effects of external actors. Incentives to build a liberal democracy have given way to a new competitive authoritarian era. The autocrats of the Western Balkans have used domestic, regional and international crises, both real (such as the refugee flows) and constructed to gain external recognition and refocus external support away from democratic consolidation to the promise of competitive authoritarian stability.

Competitive authoritarian regimes are widespread well beyond the Western Balkans. These include EU member states such as Hungary and Poland, as well as countries that had similarly established more functional democratic structures earlier that have been eroded (i.e. Turkey) or that never existed as such (i.e. Russia). The case of the Western 
Balkans highlights the importance of external legitimacy for such regimes. The competitive authoritarian regimes discussed in this article received strategic public support ranging from election rallies to visits with key EU member state officials prior to elections. For governments who claim to seek EU accession and whose citizens support EU accession, such support is important to legitimise their rule and deflect criticism of undemocratic practice. Whereas the EU appears to have recognised this challenge in the European Commission strategy that pointed out state capture as a key regional problem, EU officials continue to embrace the competitive autocratic regimes after the strategy was released, including Donald Tusk, president of the European Council, describing Serbian president Aleksandar Vučić as his "soulmate" (Tusk 2018).

Beyond identifying the inability or unwillingness of EU institutions and key member states to clearly identity the emergence of competitive authoritarian regimes, this article seeks to argue for embedding the study of competitive authoritarian regimes more into the international environment that might provide it with direct support and legitimacy, as most cases have shown here. In addition, with a formal commitment to democracy and Western orientation, the governments of the Western Balkans that sought to reconstitute their rule in a competitive authoritarian framework did so informally, maintaining all established democratic and independent institutions. The centrality of informality requires a more subtle research approach to varying regime types that explores the practice of government and explores the invisible and informal aspects to a greater extent.

\section{Notes}

1. The term Western Balkans reflects political expediency during the 2000s to encompass the post-Yugoslav region and Albania, but not Slovenia, as it was part of the 2004 EU enlargement. With the EU membership of Croatia in 2013, it is often no longer considered part of the Western Balkans.

2. See Bertelsmann Transformation Index 2016 https://www.bti-project.org/de/index/, Economist Intelligence Unit, Democracy Index 2016: Revenge of the "deplorables", http://pages.eiu. com/rs/783-XMC-194/images/Democracy_Index_2016.pdf, Freedom House, Nations in Transit 2016, https://freedomhouse.org/sites/default/files/FH_NIT2016_Final_FWeb.pdf

3. Levitsky and Way (2010) extensively discuss the role of Western leverage, tying it to intensity of the linkages, yet explore less how Western support can also reinforce competitive authoritarian regimes (43-54).

4. The post-Yugoslav region found some inclusion in the literature that has emerged since the 2000s on hybrid regimes and other forms of "qualified" democracies (Levitsky and Way 2010), again focusing on the 1990s.

5. The causes of their collapse and transformation have been explored in detail (Bunce and Wolchik 2011; Spoerri 2014).

6. In an essay on authoritarianism in the Balkans, I have identified 10 principles. In this article, I have condensed some and focused on others. Ten rules by a 21st-century Machiavelli for the Balkan Prince, LSE Blog, 7 February 2015. Available at: http://blogs.lse.ac.uk/lsee/2015/02/07/ ten-rules-by-a-21st-century-machiavelli-for-the-balkan-prince/

7. It remains an associate member of the European People's Party (EPP).

8. These are well-documented (see Human Rights Watch 2015; Lilyana 2017).

\section{Disclosure statement}

No potential conflict of interest was reported by the author. 


\section{Notes on contributor}

Florian Bieber is a Professor of Southeast European History and Politics and Director of the Centre for Southeast European Studies at the University of Graz, Austria. He studied Political Science and History at Trinity College (USA), the University of Vienna, and Central European University (Budapest). He is the coordinator of the Balkans in Europe Policy Advisory Group (BiEPAG).

\section{References}

Bechev, Dimitar. 2018. "The 2016 Coup Attempt in Montenegro: Is Russia's Balkans Footprint Expanding?" Russia Foreign Policy Papers, Foreign Policy Research Institute, https://www.fpri. org/article/2018/04/the-2016-coup-attempt-in-montenegro-is-russias-balkans-footprintexpanding/.

Beha, Adem. 2017. Between Stabilisation and Democratisation. Elections, Political Parties and IntraParty Democracy in Kosovo. Prishtina: CPC \& FES.

Bermeo, Nancy. 2016. "On Democratic Backsliding." Journal of Democracy 27 (1): 5-19.

Bertelsmann Transformation Index. 2016. https://www.bti-project.org/de/index/.

Bieber, Florian. 2014. "Of Balkan Apples, Oranges, Grandmothers and Frogs. Comparative Politics and the Study of Southeastern Europe." In South East European Studies in a Globalizing World, edited by Promitzer Christian, 127-139. Wien: Lit Verlag.

Bieber, Florian. 2018. “The Rise (and Fall) of Balkan Stabilitocracies." Horizons, No. 10, 176-185. https:// www.cirsd.org/en/horizons/horizons-winter-2018-issue-no-10/the-rise-and-fall-of-balkanstabilitocracies.

Bieber, Florian, and Marko Kmezić. 2015. "Media Freedom in the Western Balkans." Balkans in Europe Policy Advisory Group. August. http://www.biepag.eu/wp-content/uploads/2016/10/BIEPAGMedia-Freedom-in-the-Western-Balkans.pdf.

Bieber, Florian, and Irena Ristić. 2012. "Constrained Democracy: The Consolidation of Democracy in Yugoslav Successor States." Southeastern Europe 36 (3): 373-397.

BiEPAG (Balkans in Europe Policy Advisory Group). 2017. The Crisis of Democracy in the Western Balkans. Authoritarianism and EU Stabilitocracy. Policy Brief. http://www.biepag.eu/publications/ the-crisis-of-democracy-in-the-western-balkans-authoritarianism-and-eu-stabilitocracy/.

"BIRODI: Dominacija Vučića na televizijama," [BIRODI: The domination of Vučić on Television]. 2017. Danas. March 14. http://www.danas.rs/izbori.1180.html?news_id=340998.

Boduszyński, Mietek. 2010. Regime Change in the Yugoslav Successor States. Baltimore: Johns Hopkins University Press.

Bogaards, Matthijs. 2009. "How to Classify Hybrid Regimes? Defective Democracy and Electoral Authoritarianism." Democratization 16 (2): 399-423.

Bunce, Valerie, and Sharon Wolchik. 2011. Defeating Authoritarian Leaders in Postcommunist Countries. Cambridge: Cambridge University Press.

Cohen, L., and John Lampe. 2011. Embracing Democracy in the Western Balkans. Baltimore: Johns Hopkins University Press.

Cvejić, Slobodan. 2016. Informal Power Networks, Political Patronage and Clientelism in Serbia and Kosovo. Belgrade: SeConS.

Cvetkovska, Saska, Meri Jordanovska, and Vlado Apostolov. 2014. "Web Portals in the Off-Shore Claws of the Macedonian Government-Oriented Tycoons." Southeast European Media Observatory. April 24. http://mediaobservatory.net/radar/web-portals-shore-claws-macedonian-governmentoriented-tycoons.

Dawson, James. 2014. Cultures of Democracy in Serbia and Bulgaria: How Ideas Shape Publics. Farnham and Burlington: Ashgate.

Diamond, Larry. 2002. "Thinking about Hybrid Regimes." Journal of Democracy 13 (2): 21-35.

Diamond, Larry, and Marc F. Plattner, eds. 2015. Democracy in Decline? Baltimore: Johns Hopkins University Press.

Dolenec, Danijela. 2013. Democratic Institutions and Authoritarian Rule in Southeast Europe. Colchester: ECPR Press. 
Djolai, Marika, and Corina Stratulat. 2017. "Clientalism." In The Crisis of Democracy in the Western Balkans: An Anatomy of Stabilitocracy and the Limits of EU Democracy Promotion, edited by Marko Kmezić, and Florian Bieber, 73-90. Belgrade: Balkans in Europe Policy Advisory Group.

Džankić, Jelena. 2013. "Cutting the Mists of the Black Mountain: Cleavages in Montenegro's Divide over Statehood and Identity." Nationalities Papers 41 (3): 412-430.

Džankić, Jelena. 2014. "From Creeping to Sprinting: The Foreign Policy of Montenegro." In The Foreign Policies of Post-Yugoslav States from Yugoslavia to Europe, edited by Soeren Keil, and Berhard Stahl, 173-198. Basingstoke: Palgrave.

Džankić, Jelena, and Soeren Keil. 2017. "State-Sponsored Populism and the Rise of Populist Governance: The Case of Montenegro." Journal of Balkan and Near Eastern Studies 19 (4): 403-418.

Džihić, Vedran, and Dieter Segert. 2012. "Lessons from 'Post-Yugoslav' Democratization. Functional Problems of Stateness and the Limits of Democracy." East European Politics and Societies 26 (2): 239-253.

EC (European Commission). 2016. "The Former Yugoslav Republic of Macedonia 2016 Report." Brussels. November 9. https://ec.europa.eu/neighbourhood-enlargement/sites/near/files/pdf/ key_documents/2016/20161109_report_the_former_yugoslav_republic_of_macedonia.pdf.

EC (European Commission). 2018. "A Credible Enlargement Perspective for and Enhanced EU Engagement with the Western Balkans." Strasbourg, February 6. https://ec.europa.eu/ commission/sites/beta-political/files/communication-credible-enlargement-perspective-westernbalkans_en.pdf.

Economist Intelligence Unit. 2016. "Democracy Index 2016: Revenge of the 'Deplorables'." http:// pages.eiu.com/rs/783-XMC-194/images/Democracy_Index_2016.pdf.

Ernst, Andreas. 2017. "Vucic, der Machiavellist," [Vučić: the Machiavellian] Neue Zürcher Zeitung. April 3. https://www.nzz.ch/international/wahl-in-serbien-durchmarsch-von-vucic-ins-praesidentenamtId.155050.

Fazekas, Mihály, and István János Tóth. 2016. “From Corruption to State Capture. A New Analytical Framework with Empirical Applications from Hungary." Political Research Quarterly 69 (2): 195-206.

Fisher, Sharon. 2006. Political Change in Post-Communist Slovakia and Croatia: From Nationalist to Europeanist. London: Palgrave Macmillan.

Freedom House. 2016. "Nations in Transit 2016." https://freedomhouse.org/sites/default/files/FH_ NIT2016_Final_FWeb.pdf.

Gagnon, V. P. Jr. 2004. The Myth of Ethnic War. Ithaca: Cornell University Press.

Gordy, Eric. 1999. The Culture of Power in Serbia. College Park: Pennsylvania State University Press.

Günay, Cengiz, and Vedran Džihić. 2016. “Decoding the Authoritarian Code: Exercising 'Legitimate' Power Politics Through the Ruling Parties in Turkey, Macedonia and Serbia." Southeast European and Black Sea Studies 16 (4): 529-549.

Hopkins, Valery. 2017. "Indictment Tells Murky Montenegrin Coup Tale." Politico. May 23. http://www. politico.eu/article/montenegro-nato-milo-dukanovicmurky-coup-plot/.

Human Rights Watch. 2015. "A Difficult Profession. Media Freedom under Attack in the Western Balkans." July 15. https://www.hrw.org/report/2015/07/15/difficult-profession/media-freedomunder-attack-western-balkans.

Irion, Kristina, and Tarik Jušić. 2014. "International Assistance and Media Democratization in the Western Balkans: A Cross-National Comparison," Analitika. Working Papers. April. http://www. analitika.ba/en/publications/international-assistance-and-media-democratization-westernbalkans-cross-national.

Jordanovska, Meri. 2015. "True Cost of 'Skopje 2014' Revealed." Balkan Insight. July 27. http://www. balkaninsight.com/en/article/true-cost-of-skopje-2014-revealed.

Kmezić, Marko, and Florian Bieber. 2015. Media Freedom in the Western Balkans. Background Papers, Balkans in Europe Policy Advisory Group.

Konitzer, Andrew. 2011. "Speaking European: Conditionality, Public Attitudes and Pro-European Party Rhetoric in the Western Balkans." Europe-Asia Studies 63 (10): 1853-1888.

Krastev, Ivan. 2007. "The Strange Death of the Liberal Consensus." Journal of Democracy 18 (4): 56-63. Krastev, Ivan. 2011. "Paradoxes of the New Authoritarianism." Journal of Democracy 22 (2): 5-16. 
Levitsky, Steven, and Lucan A. Way. 2010. Competitive Authoritarianism. Hybrid Regimes after the Cold War. Cambridge: Cambridge University Press.

Levitsky, Steven, and Lucan A. Way. 2015. "The Myth of Democratic Recession." Journal of Democracy 26 (1): 45-58.

Levitsky, Steven, and Daniel Ziblatt. 2018. How Democracies Die. New York: Crown.

Levitz, Philip, and Grigore Pop-Eleches. 2010. "Why No Backsliding? The European Union's Impact on Democracy and Governance Before and After Accession." Comparative Political Studies 43 (4): 457485.

"Liderot na najgolemata politička partija vo Evroupa so silna poddrška za VMRO-DPMNE," [Leader of the largest political party in Europe gives from strong support to VMRO-DPMNE]. 2016. Vest. December 1. http://www.vest.mk/default.asp?ltemID=3D7817B2FF57B142AE19CCDD0A552DF8.

Lilyana, Velina. 2017. "Western Balkans: Media Freedom Trends 2017." European Parliament Think Tank. April 27, 2017. http://www.europarl.europa.eu/RegData/etudes/ATAG/2017/603888/EPRS_ ATA(2017)603888_EN.pdf, see also RSF ranking https://rsf.org/en/ranking\#.

Marko, Davor. 2016. "The Future of Public Service Broadcasting in the Western Balkans: The Need for a New paradigm," Sarajevo: Centre for Social Research Analitika. http://www.analitika.ba/en/ publications/buducnost-javnih-servisa-na-zapadnom-balkanu-u-potrazi-za-novom-paradigmom.

Marović, Jovana, and Srdjan Cvijić. 2017. "Elections." In The Crisis of Democracy in the Western Balkans. An Anatomy of Stabilitocracy and the Limits of EU Democracy Promotion, edited by Marko Kmezić, and Florian Bieber, 15-32. Belgrade: Balkans in Europe Policy Advisory Group.

Marusic, Sinisa Jakov. 2016. "Austrian FM Defends Decision to Back Macedonia Ruling Party." Balkan Insight. November 28. http://www.balkaninsight.com/en/article/critics-slam-kurz-s-support-formacedonia-s-ruling-party-11-28-2016.

Merkel, Wolfgang. 2004. "Embedded and Defective Democracies." Democratization 11 (5): 33-58.

Mudde, Cas, and Cristóbal Rovira Kaltwasser. 2016. Populism: A Very Short Introduction. Oxford: Oxford University Press.

Mujanović, Jasmin. 2018. Hungary and Fury. The Crisis of Democracy in the Balkans. London: Hurst and Co.

Öktem, Kerem, and Karabekir Akkoyunlu, eds. 2017. Exit from Democracy: Illiberal Governance in Turkey and Beyond. London: Routledge.

Orlović, Slaviša. 2008. Politički život Srbije. Izmedju partokratiji i demokratijie. Belgrade: Službeni glasnik.

Ottaway, Marina. 2003. Democracy Challenged: The Rise of Semi-Authoritarianism. Washington, DC: Carnegie Endowment for International Peace.

Pavlović, Dušan. 2016a. Mašina za rasipanje para. Pet meseci u ministarstvu privrede [The Money Wasting Machine: Five Months in the Ministry of Economics]. Belgrade: Dan Graf.

Pavlović, Srđa. 2016b. "Montenegro's 'stabilitocracy': The West's support of Đukanović is damaging the prospects of democratic change." LSE Europp Blog. December 23. http://bit.ly/2ihqgrs.

Petkovski, Ljupcho. 2015. "Authoritarian Populism and Hegemony: Constructing 'the People' in Macedonia's Illiberal Discourse." Contemporary Southeastern Europe 3 (2): 44-66. http://www. suedosteuropa.uni-graz.at/cse/en/petkovski.

Primatarova, Antoinette, and Johanna Deimel. 2012. "Bridge over Troubled Waters? The Role of the Internationals in Albania." Center for Liberal Strategies, Sofia. http://www.cls-sofia.org/en/ forthcoming-events/bridge-over-troubled-waters-the-role-of-the-internationals-in-albania- 180 .

html.

Radovanović, Rade. 2015. “Premijera najavljenog državnog udara u Srbiji [Premiere of an Announced Coup in Serbia]." Al Jazeera. November 30. http://balkans.aljazeera.net/vijesti/premijeranajavljenog-drzavnog-udara-u-srbiji.

Snyder, Timothy. 2017. "The Reichstag Warning." New York Review of Books. February 26. http://www. nybooks.com/daily/2017/02/26/reichstag-fire-manipulating-terror-to-end-democracy/.

Spoerri, Marlene. 2014. Engineering Revolution. The Paradox of Democracy Promotion in Serbia. Philadelphia: University of Pennsylvania Press.

Stanković, Ana, Katarina Ćuković, and Tijana Vuksanović. 2016. "Programska platforma liste Aleksandar Vučić - Srbija pobeđuje na parlamentarnim izborima 2016. Godine 
[The Programmatic Platform of the List Aleksandar Vučić-Serbia Wins in the Parliamentary Elections 2016]." In Stranke i javne politika. Izbori u Srbiji 2016. Godine [Parties and Public Policy. Elections in Serbia 2016], edited by Gordana Pilipović and Zoran Stojiljković, 101-123. Belgrade: Konrad-Adenauer-Stiftung.

Treisman, Daniel. 2011. "Presidential Popularity in a Hybrid Regime: Russia under Yeltsin and Putin." American Journal of Political Science 55 (3): 590-609.

Tusk, Donald. 2018. "Remarks by President Donald Tusk after His Meeting with President Aleksandar Vučić of Serbia." February 25. http://www.consilium.europa.eu/en/press/press-releases/2018/04/ 25/remarks-by-president-donald-tusk-after-his-meeting-with-president-aleksandar-vucic-ofserbia/pdf.

Vachudova, Milada Ana. 2014. "EU Leverage and National Interests in the Balkans: The Puzzles of Enlargement Ten Years On." JCMS: Journal of Common Market Studies 52 (1): 122-138.

Vangeli, Anastas. 2011. "Nation-Building Ancient Macedonian Style: The Origins and the Effects of the So-Called Antiquization in Macedonia." Nationalities Papers 39 (1): 13-32.

Vladisavljević, Nebojša. 2014. "Does Scholarly Literature on the Breakup of Yugoslavia Travel Well?" In Debating the End of Yugoslavia, edited by Florian Bieber, Armina Galijaš, and Rory Archer, 67-80. Farnham: Ashgate.

Vračić, Alida, and Bleriana Bino. 2017. "Media." In The Crisis of Democracy in the Western Balkans. An Anatomy of Stabilitocracy and the Limits of EU Democracy Promotion, edited by Marko Kmezić, and Florian Bieber, 55-71. Balkans in Europe Policy Advisory Group (BiEPAG). http://www.biepag.eu/ wp-content/uploads/2017/05/final.pdf.

"Vučić: Pobeda čista kao suza, nije mala razlika," [Vučić: Victory is clean as tears, not a small difference]. 2017. N1. April 2. http://rs.n1 info.com/a239510/Vesti/Vesti/Obracanje-Vucica-nakonizbora.html.

Vuković, Ivan. 2015. "Political Dynamics of the Post-Communist Montenegro: One-Party Show." Democratization 22 (1): 73-91.

White, Jonathan. 2015. “Emergency Europe." Political Studies 63 (2): 300-318. 